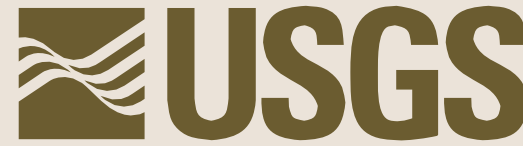

science for a changing world

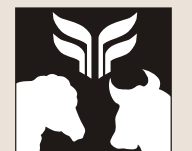

Wyoming Department of Agriculture (WDA)

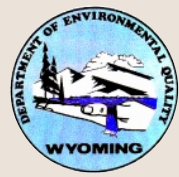

Wyoming Department of

Environmental Quality (WDE0),

Water Quality Division

In cooperation with the Wyoming Department of Agriculture (WDA), the Wyoming Department of Environmental Quality (WDEQ), and the Laramie County Conservation District

\title{
Pesticides in Ground Water - Laramie County, Wyoming, 1998-99
}

In 1991, members of local, State, and Federal governments, as well as industry and interest groups, formed the Ground-water and Pesticide Strategy Committee to prepare the State of Wyoming's generic Management Plan for Pesticides in Ground Water. Part of this management plan is to sample and analyze Wyoming's ground water for pesticides. In 1995, the U.S. Geological Survey, in cooperation with the Ground-water and Pesticide Strategy Committee, began statewide implementation of the sampling component of the State of Wyoming's generic Management Plan for Pesticides in Ground Water. In 1998, baseline monitoring began in Laramie County.

\section{PESTICIDES IN GROUND WATER}

Synthetic organic pesticides are used to control weeds, insects, and other organisms in a wide variety of agricultural and nonagricultural settings. The use of pesticides has helped to make the United States the world's largest producer of food (Barbash and Resek, 1996). Pesticide use, however, has also been accompanied by concerns about potential adverse effects on the environment and human health. A potential pathway for the transport of pesticides is through hydrologic systems, which supply water for both humans and natural ecosystems. Water is one of the primary ways pesticides are transported from an application area to other locations in the environment (fig. 1) (Barbash and Resek, 1996).

Pesticide contamination of ground water is a national issue because of the widespread use of pesticides, the expense and difficulty of remediating ground water, and the fact that ground water is used for drinking water by about

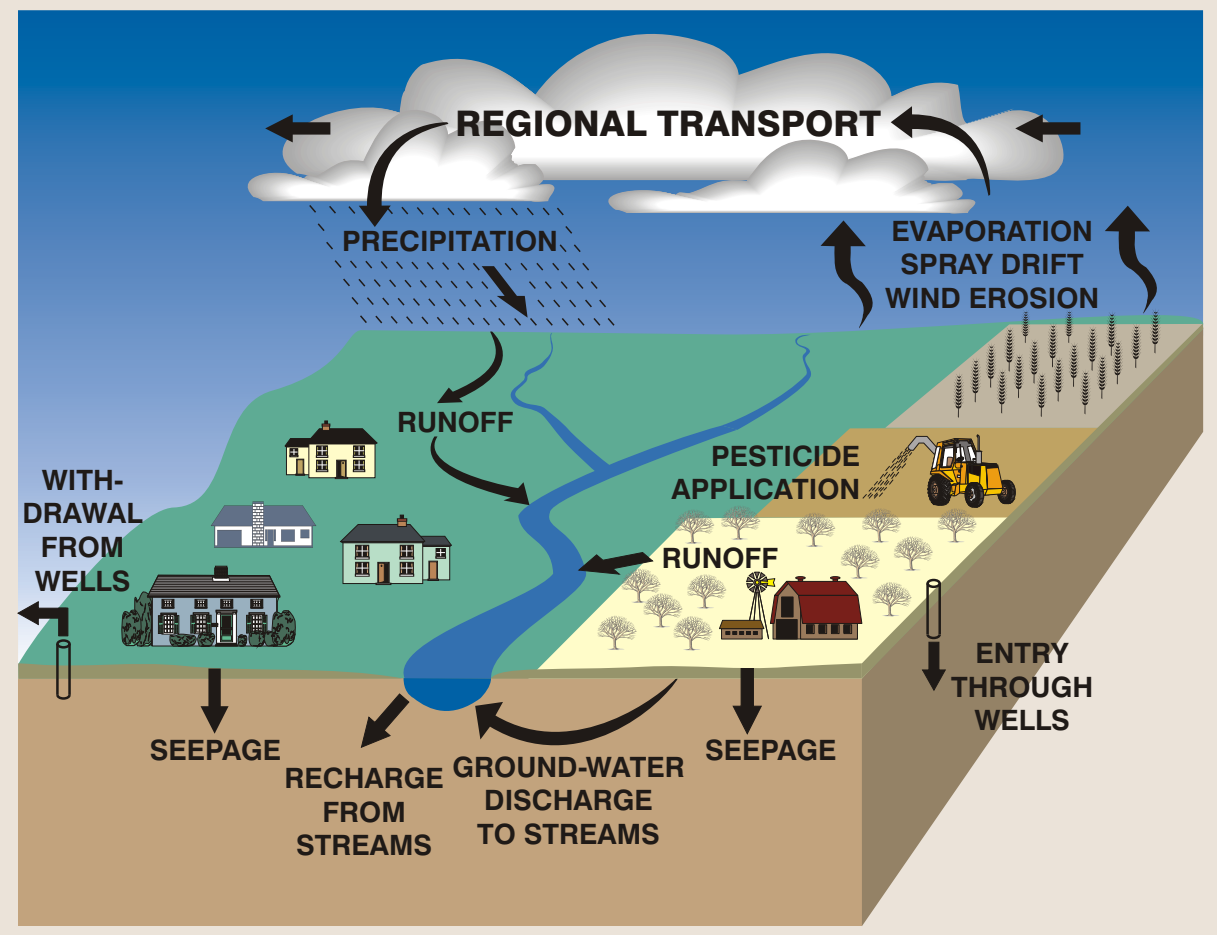

Figure 1. Pathways of pesticide movement in the hydrologic cycle (modified from Barbash and Resek, 1996).

50 percent of the Nation's population. Concern about pesticides in ground water is especially acute in rural agricultural areas where over 95 percent of the population relies upon ground water for their drinking water (Solley and others, 1998), although application rates and the variety of pesticides used may be greater in urban areas.

\section{WYOMING'S PESTICIDE MANAGEMENT PLAN}

The Ground-water and Pesticide Strategy Committee (GPSC) has developed the generic State Management Plan for Pesticides in Ground Water for the State of Wyoming (SMP) (Wyoming Ground-water and Pesticides Strategy Committee, 1999). The SMP is required by the U.S. Environmental Protection Agency (EPA) in order for individuals and organizations to continue using certain pesticides in Wyoming. The SMP includes information relating to individuals and organizations involved with the implementation of the SMP, methods of preventing ground-water contamination, ground-water monitoring, and what the responses will be if pesticides are detected in ground water.

One critical part of the SMP is ground-water monitoring. The groundwater monitoring program has two phases. The first phase involves baseline monitoring, which is an initial survey of pesticides in a county's ground water. The second phase is problem identification monitoring, which is used to gather more information about the ground water 
Table 1. Baseline monitoring for pesticides in Laramie County, 1998-99.

[ $\mu \mathrm{g} / \mathrm{L}$, micrograms per liter; trace indicates pesticide detected, but at a concentration too small to quantify; NA, not applicable]

\begin{tabular}{|c|c|c|c|c|c|c|c|}
\hline Pesticide & $\begin{array}{l}\text { Pesticide } \\
\text { trade name }\end{array}$ & Pesticide action ${ }^{1}$ & $\begin{array}{l}\text { Number of } \\
\text { detections/ } \\
\text { number of } \\
\text { samples }^{2}\end{array}$ & $\begin{array}{l}\text { Laboratory } \\
\text { minimum } \\
\text { reporting limit } \\
(\mu \mathbf{g} / \mathrm{L})\end{array}$ & $\begin{array}{c}\text { Maximum } \\
\text { concentration } \\
(\mu \mathrm{g} / \mathrm{L})\end{array}$ & $\begin{array}{c}\text { Average } \\
\text { concentration } \\
\text { of detections } \\
(\mu \mathrm{g} / \mathrm{L})\end{array}$ & $\begin{array}{c}\text { Safe drinking } \\
\text { water standard } \\
(\mu \mathrm{g} / \mathrm{L})\end{array}$ \\
\hline \multicolumn{8}{|c|}{ Focal pesticides detected in Laramie County ground water } \\
\hline Alachlor & Lasso & Pre-emergence herbicide & $1 / 32$ & 0.002 & trace & NA & 2 \\
\hline Atrazine & Aatrex & Selective herbicide & $14 / 32$ & 0.001 & 0.4 & 0.08 & 3 \\
\hline Bromacil & Hyvar XL & Herbicide & $2 / 32$ & 0.04 & 0.06 & 0.06 & 90 \\
\hline Hexazinone & Velpar & Selective herbicide & $1 / 32$ & 0.03 & trace & NA & ${ }^{4} 200$ \\
\hline Metolachlor & Dual & Selective herbicide & $2 / 32$ & 0.002 & 0.06 & 0.03 & ${ }^{4} 70$ \\
\hline Metribuzin & Lexone, Sencor & Herbicide & $1 / 32$ & 0.004 & 0.01 & NA & 100 \\
\hline Picloram & Tordon & Systemic herbicide & $7 / 32$ & 0.05 & 4 & 1 & 500 \\
\hline Simazine & Princep & Selective herbicide & $3 / 32$ & 0.005 & 0.1 & 0.07 & 4 \\
\hline Tebuthiuron & Spike & Herbicide & $4 / 32$ & 0.01 & 0.05 & 0.03 & ${ }^{4} 500$ \\
\hline \multicolumn{8}{|c|}{ Non-focal pesticides detected in Laramie County ground water } \\
\hline Diuron & Farmco & Herbicide & $4 / 32$ & 0.02 & 3 & 0.7 & ${ }^{5} 70$ \\
\hline Prometon & Pramitol & Non-selective herbicide & $7 / 32$ & 0.02 & 0.3 & 0.1 & ${ }^{4} 100$ \\
\hline \multicolumn{8}{|c|}{ Focal pesticides not detected in Laramie County ground water } \\
\hline & \multicolumn{3}{|c|}{$\begin{array}{l}2,4-D \\
\text { Aldicarb }\end{array}$} & $\begin{array}{l}\text { Clopyralid } \\
\text { Cyanazine }\end{array}$ & $\begin{array}{l}\text { DCPA } \\
\text { Dicamba }\end{array}$ & Telone & \\
\hline & \multicolumn{7}{|c|}{ Focal pesticides not analyzed in Laramie County ground water (no method of analysis available) } \\
\hline & \multicolumn{3}{|c|}{ Difenzoquat } & \multicolumn{2}{|c|}{ Metsulfuron } & & \\
\hline
\end{tabular}

${ }^{1}$ Meister, R.T., 1996

${ }^{2}$ Each of the 16 wells were sampled twice.

${ }^{3}$ EPA Maximum Contaminant Level unless otherwise noted (EPA, 1996).
${ }^{4}$ EPA Lifetime health Advisory level (EPA, 1996).

${ }^{5}$ WDEQ Drinking Water Equivalent Level (WDEQ, 1993).

${ }^{6}$ Degradation product of Aldicarb. near wells with significant pesticide detections.

Baseline monitoring is prioritized by a county rank and the vulnerability of the county's ground water to pesticides.

During the development of the SMP, the GPSC evaluated each county in Wyoming to determine the potential vulnerability of the county's ground water to pesticides. Each county was ranked based on the extent of cropland and urban areas in the county, as well as the amount of pesticides sold within the county in 1991 (Wyoming Ground-water and Pesticides Strategy Committee, 1999).

A ground-water vulnerability map was prepared for the uppermost or shallowest aquifer by the University of Wyoming Spatial Data and Visualization

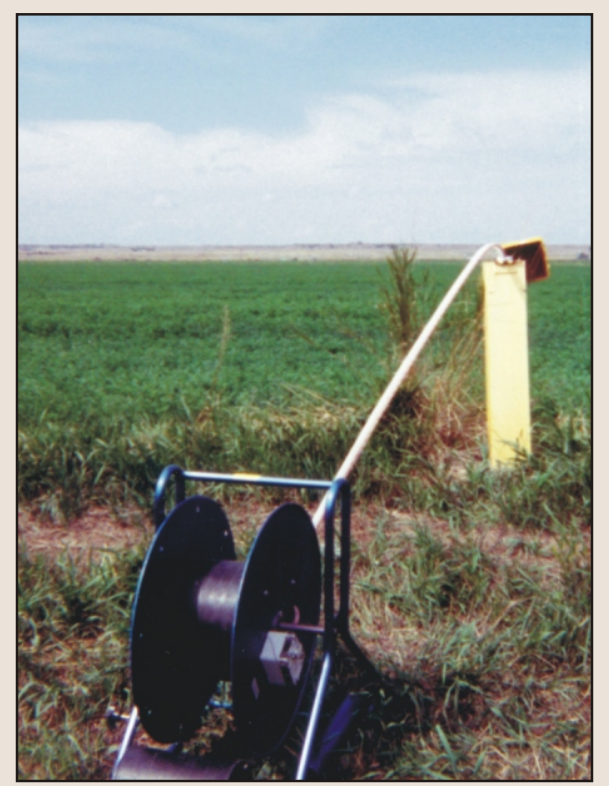

Center (SDVC). A Geographic Information System was used to overlay seven coverages describing hydrogeology and land use. The map produced was used to assist in the selection of monitoring sites in each county. The monitoring focuses on areas where the ground water is most vulnerable.

The GPSC selected 18 pesticides (focal pesticides) and 2 degradation products to be sampled as part of the SMP (table 1). An additional 66 pesticides and degradation products are included in the U.S. Geological Survey analytical protocol, resulting in possible detections of non-focal pesticides. Ground water from all wells in the baseline monitoring program was analyzed for the pesticides listed in table 1, with the exception of difenzoquat and metsulfuron because analytical methods were not available for their analysis. 


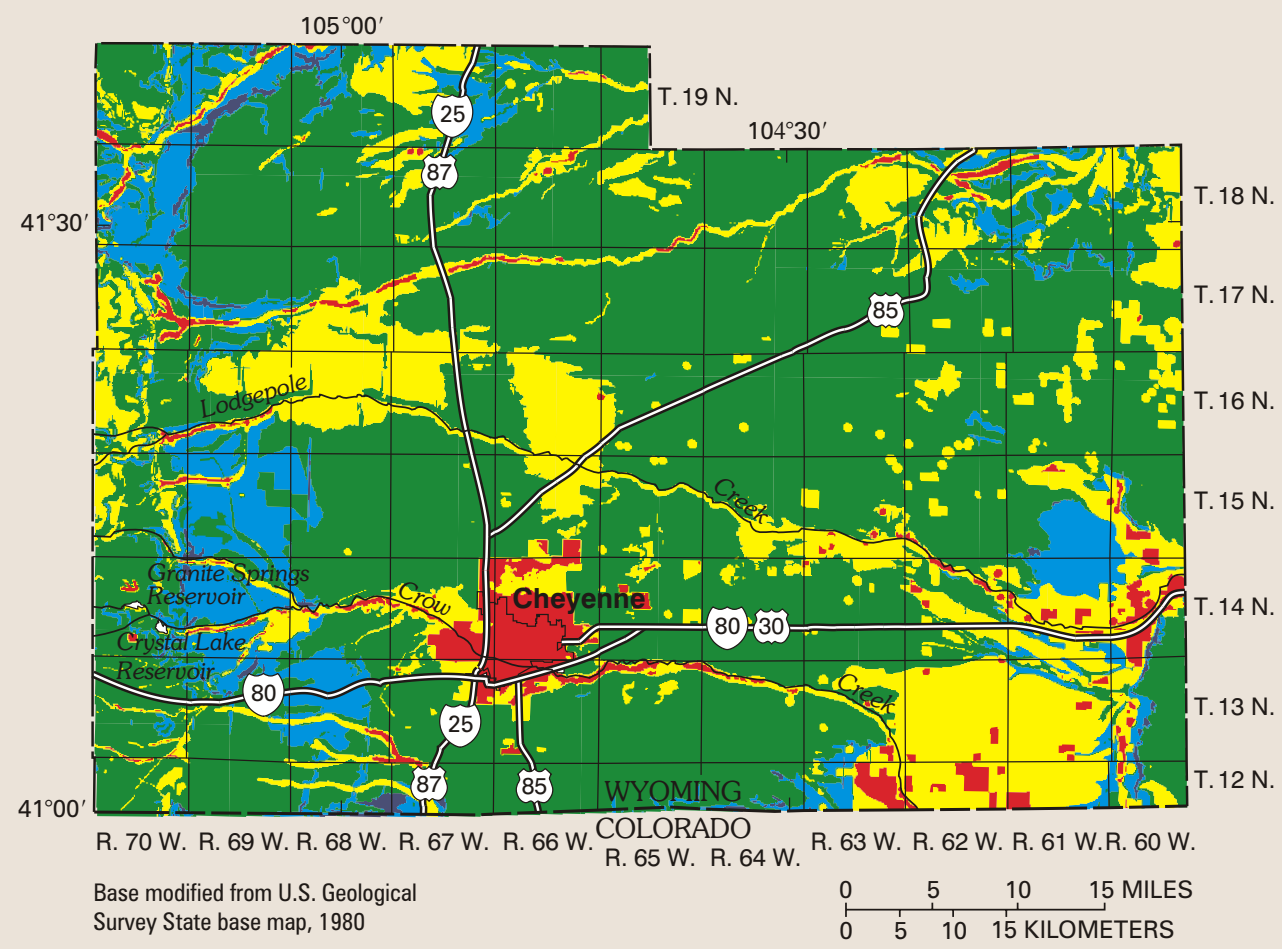

\section{EXPLANATION}

\section{VULNERABILITY TO PESTICIDE CONTAMINATION}

\begin{tabular}{ll}
\hline High & Medium low \\
$\square$ & Medium high $\square$ Low \\
$\square$ & Medium
\end{tabular}

Figure 2. Vulnerability of Laramie County ground water to pesticide contamination (from Hammerlink and Arneson, 1998).

The goal of the sampling program is to collect ground-water samples for pesticide analyses in all 23 Wyoming counties. The ground-water sampling part of the SMP began in Goshen County in 1995. Sampling in Park and Washakie Counties was conducted in 1997, and completed by 1998. In August 1998, sampling began in Fremont, Lincoln, and Laramie Counties. The sampling for these three counties was completed in May 1999.

\section{GROUND-WATER MONITORING IN LARAMIE COUNTY}

The ground water in Laramie County was ranked the sixth most vulnerable to to pesticide contamination in Wyoming. The vulnerability map for Laramie County (fig. 2) was created by the SDVC (Hammerlink and Arneson, 1998). Shallow alluvial and terrace deposits, and urban and suburban areas in and near Cheyenne were identified as the most vulnerable areas in the county.

Sixteen sites were selected for baseline monitoring in Laramie County (fig. 3). All wells were located in the most vulnerable areas (shown as red and yellow in fig. 2). The wells were inspected and selected with the assistance of the Laramie County Conservation District. All sites were sampled twice, late summer 1998 and spring 1999. These time periods were selected to correspond with the shallowest or deepest water-table conditions.

Nine of the 18 focal pesticides and 2 non-focal pesticides were detected in Laramie County (table 1). At least one pesticide was detected in 11 of the 16 wells sampled in Laramie County. All concentrations of pesticides were less than the drinking water standards (U.S. Environmental Protection Agency, 1996). The laboratory minimum reporting limit is the lowest concentration at which the pesticide can be quantified. One-third of the detections were trace quantities. A trace quantity indicates the pesticide was detected, but at a concentration too small to quantify.

The most commonly detected pesticide in Laramie County was atrazine. Atrazine was also the most commonly detected pesticide in Goshen, Park, Washakie, and Fremont Counties. Atrazine is an agricultural herbicide typically used for weed control in corn and other crops (Farm Chemicals Handbook, 1996).

Other frequently detected pesticides in Laramie County were picloram and prometon. Picloram is the active ingredient in Tordon and prometon is the active ingredient in Pramitol. Picloram was detected in 5 wells in Laramie County, all of which were located in rural settings. Picloram was the pesticide detected at highest concentration in Laramie County ground water at 4 micrograms per liter (parts per billion) Picloram, an herbicide, is one of the most commonly used pesticides in Wyoming. Prometon was detected in four wells in the county, three of which were located within the city of Cheyenne. Prometon is a general use pesticide and its detection is typically associated with urban land use (Barbash and others, 1999).

\section{MONITORING STATUS AND DATA AVAILABILITY}

The sampling results have been given to local groups interested in pesticides in ground water in Laramie County. The information can be used by citizens and local governments to help understand current conditions. Results of the Laramie County sampling can be found in Mason and others, 1999, and Swanson and others, 2000. Results of all analyses, including sampling of all counties to date, are available from the U.S. Geological Survey in Cheyenne.

\footnotetext{
- Prepared by Cheryl A. Eddy-Miller and Jodi R. Norris

- Layout and final illustrations by Suzanne C. Roberts
} 


\section{REFERENCES:}

Barbash, J.E., and Resek, E.A., 1996, Pesticides in ground water--Distribution trends, and governing factors: Ann Arbor Press, Chelsea, Michigan, p. 3

Barbash, J.E., Thelin, G.P., Kolpin, D.W., and Gillom, R.J., 1999, Distribution of major herbicides in ground water of the United States: U.S. Geological Survey Water-Resources Investigations Report 98-4245, $64 \mathrm{p}$.

Hammerlink, J.D., and Arneson, C.S., editors, 1998, Wyoming ground water vulnerability assessment handbook: Volume 2. Assessing ground water vulnerability to pesticides: Spatial Data and Visualization Center Publication SDVC 98-01-2, University of Wyoming, Laramie, Wyoming, variable pagination.

Mason J.P., Miller, D.T., and Ogle, K.M., 1999, Water resources data, Wyoming, water year 1998, Volume 2. Ground Water: U.S. Geological Survey WaterData Report WY-98-2, 127 p.

Meister, R.T., 1996, Farm Chemicals Handbook: Willoughby, Ohio, Meister Publishing Co., variable pagination.

Solley, W.B., Pierce, R.R., and Perlman, H.A., 1998, Estimated use of water in the United States in 1995: U.S. Geological Survey Circular 1200, 71 p.

Swanson, R.B., Mason, J.P., and Miller, D.T., 2000, Water-resources data, Wyoming, water year 1999, Volume 2. Ground Water: U.S. Geological Survey Water-Data Report WY-99-2.

U.S. Environmental Protection Agency, 1996, Drinking water regulations and health advisories: EPA 822-B-96-002.

Wyoming Department of Environmental Quality, 1993, Procedures for establishing environmental restoration standards for leaking underground storage tank remediation actions, WDEQ/WQD Rules and Regulations, Chapter XVII.

Wyoming Ground-water and Pesticides Strategy Committee, 1999, Wyoming generic state management plan for pesticides and ground water: prepared for Wyoming Department of Agriculture, Cheyenne, Wyoming, $103 \mathrm{p}$.

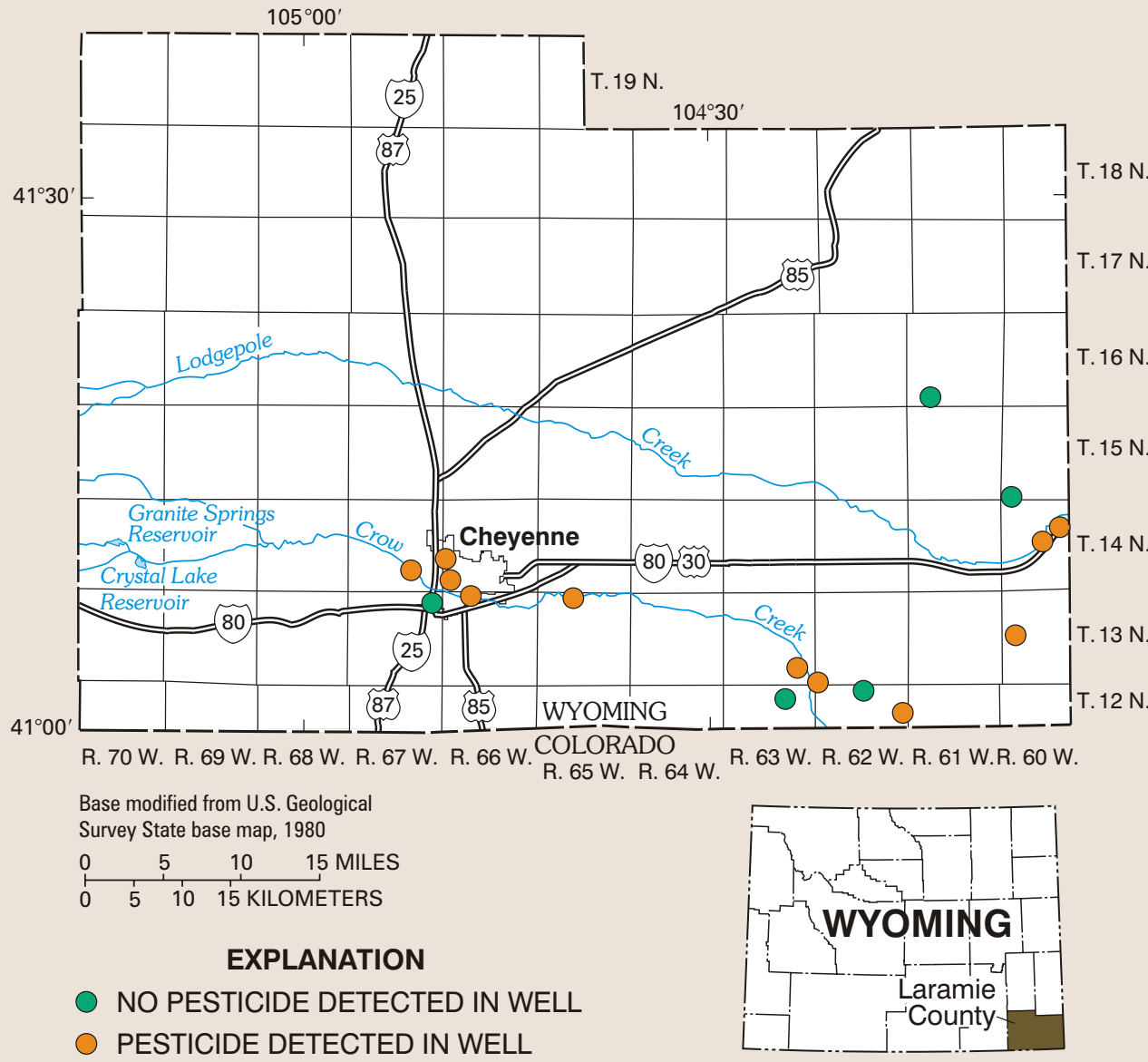

Figure 3. Location of wells sampled in Laramie County, and notation of pesticide detection in each well.

\section{FOR MORE INFORMATION, CONTACT:}

\section{Jim Bigelow}

Wyoming Department of Agriculture

2219 Carey Avenue

Cheyenne, Wyoming 82002

(307) 777-7324

\section{Kevin Frederick}

Wyoming Department of Environmental Quality, Water Quality Division

4th Floor, Herschler Building

Cheyenne, Wyoming 82002

(307) 777-7781

\section{District Chief}

U.S. Geological Survey, WRD

2617 E. Lincolnway, Suite B

Cheyenne, Wyoming 82001

(307) 778-2931

Email: state_rep_wy@usgs.gov

Internet: http://wy.water.usgs.gov/
This document was prepared by the U.S. Geological Survey (USGS), the Wyoming Department of Agriculture (WDA), and the Wyoming Department of Environmental Quality, Water Quality Division (WDEQ). All agencies are members of the Ground- water and Pesticide Strategy Committee.

This project has been funded in part with a Section 319 grant from the U.S. Environmental Protection Agency to Wyo. Dept. of Environmental Quality's Non-Point Source Program.

The use of trade, product, industry, or firm names is for descriptive purposes only and does not imply endorsement by the U.S. Government. 